\title{
Economic Impact of World Bank Aviation Investment in Pacific
}

\section{Island Countries}

\author{
Cindy Greenman ${ }^{1 *} \&$ Javad Gorjidooz ${ }^{1}$ \\ ${ }^{1}$ Business Department, Embry Riddle Aeronautical University, Prescott, Arizona, USA \\ *Cindy Greenman, E-mail: greenmac@erau.edu
}

Received: June 12, 2017

Accepted: June 26, 2017

Online Published: July 21, 2017

doi:10.22158/jepf.v3n3p343

URL: http://dx.doi.org/10.22158/jepf.v3n3p343

\begin{abstract}
The World Bank Group (WBG) has provided grant and credits to support projects related to aviation and air transport including capacity building, policy and regulation, safety and security, infrastructure rehabilitation, and institutional strengthening for over 60 years. Today, the WBG remains actively engaged on aviation related project in every region of the world including the Pacific Island Countries. The purpose of this paper is to investigate the economic impact of WBG investments in aviation infrastructures in Pacific Island Countries.

The preliminary results of this study show a serious deficiency in the areas of aviation infrastructure, safety and security, management efficiency, and airport environmental sustainability in the Pacific Island countries. Without a dynamic aviation industry, most developing countries would see a drastic reduction in tourism, resulting in an economic slowdown. In Pacific Island countries, if these aviation infrastructure deficiency continued to go unaddressed, they would likely lead to the end of international flight operations to the airports in this region. Therefore, the WBG investments in aviation infrastructure is necessary in this region to support tourism, economic development, job creation, and higher standard of living in for Pacific Islanders.
\end{abstract}

\section{Keywords}

World Bank, Pacific Islands, aviation, Pacific Aviation Project

\section{Introduction}

The population of the Pacific Islands are spread across many small islands where tourism is a major contributor to the overall GDP. "It's estimated that the tourism industry accounts for one fifth of GDP and employment in the South Pacific" (Note 1). The WBG Pacific Aviation Investment Project was proposed in May of 2011. The project included the Republic of Kiribati, the Kingdom of Tonga and the Pacific Aviation Security Office in Vanuatu. The first phase of the project included participants in Kiribati and Tonga. They planned for future projects in Samoa, Solomon Islands, Timor, Tuvalu, and Vanuatu. 
Preliminary studies in this region showed serious deficiencies in the areas of aviation infrastructure, safety and security. The Kiribati Country Assistance Strategy (CAS) proposed to the World Bank Board in March of 2011 the idea of airport rehabilitation. Initial inspections by the International Civil Aviation Organization (ICAO) found that many of the runways in the area were in abysmal condition and navigational aids were basic or missing all together. If these issues continued to go unaddressed, they would likely lead to the end of international flight operations to the airports in that region. The Pacific Aviation Investment Project was intended to support the World Bank's Engagement Framework for the Pacific Islands that is focused on reducing barriers to trade and investment, promoting tourism, human resource development and environmental management. The basis of this framework was initially focused on climate change and transportation infrastructure with the possibility of future investments.

The statuses of WBG active investments in the Pacific Island Countries as of 2015 are presented in Table 1 and the project in the pipeline are presented in Table 2.

\section{WBG's Project Objectives}

The World Bank Group mission is to provide financial and technical assistance to under-developed and developing countries around the world by offering low-interest loans, grants, credits, and advisory services. Major objectives of the WBG is to achieve the following two goals by 2030 (Note 2):

1. End extreme poverty by decreasing the percentage of people living on less than $\$ 1.25$ a day to no more than 3 percent.

2. Promote shared prosperity by boosting the income of the bottom $40 \%$ of the population in every country.

The objectives of the WBG in Pacific Island Countries initial project were to "(1) Improve the safety, security, efficiency, management and environmental sustainability of airports, and (2) improve regional harmonization of aviation safety standards" (Note 3).

Table 1. WBG Grants for Aviation Investment Projects in Pacific Island Countries

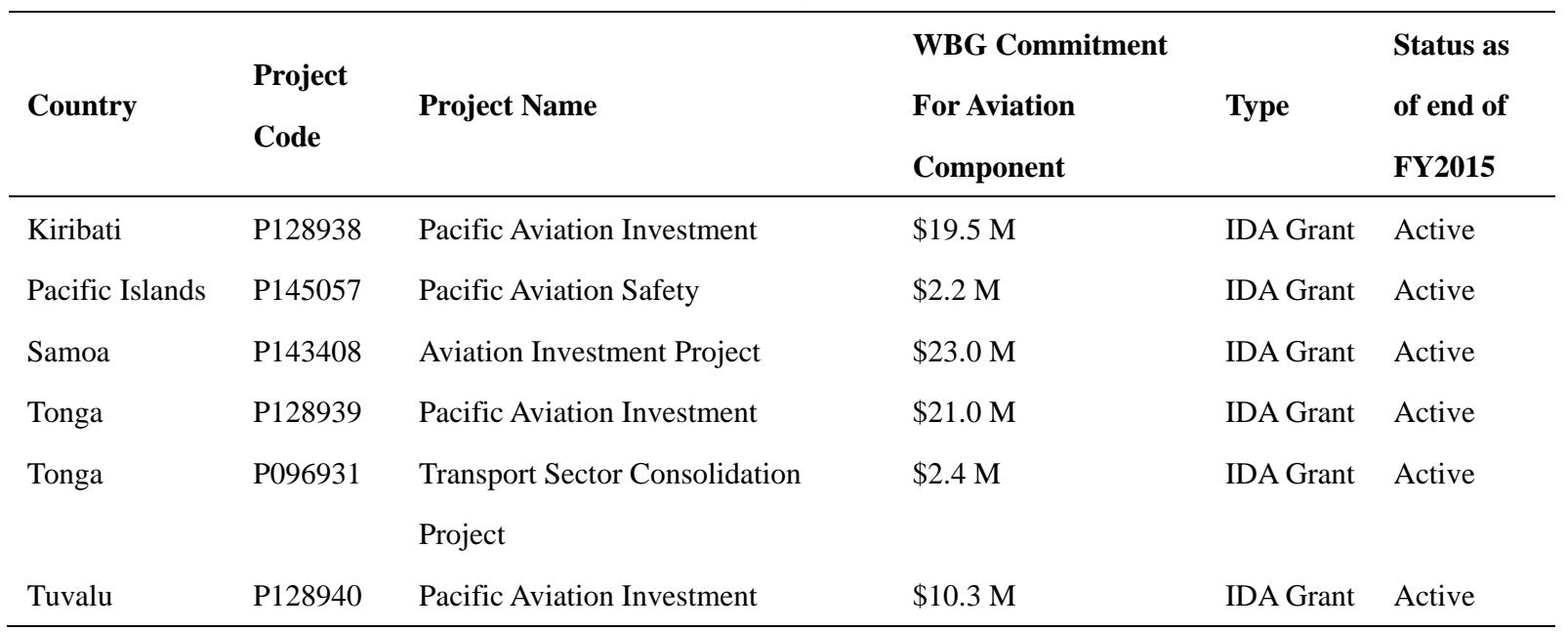




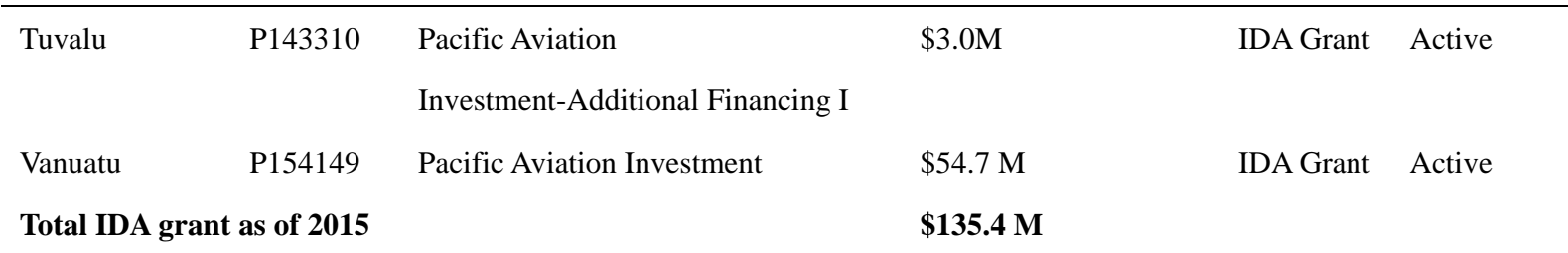

The project would include four separate components.

1. Aviation Infrastructure Investment (\$33.2 mil) — upgrade airports to meet the ICAO standards and extend the service life of the existing airport assets.
a. Restoration of airport runways, aprons and taxiways
b. Implementation of discrete photovoltaic on-site power generation (a solar park).
c. Upgrades to terminals in order to reduce electrical consumption.
d. Improving runway lighting using lower power consuming equipment.
e. Improve security through access control, $\mathrm{x}$-ray equipment, and building management system.
f. Harvest rain water at all airports, facilities from roof areas in order to reduce the demand for potable water and preserve natural water resources.
g. Improve navigational aids at all airports.
h. Provide fire tenders and fire equipment for all airports.
i. Establish weather monitoring observation stations for all airports.
j. Hire consultants to assist in design and preparation of technical specification on aviation equipment implementation.

Table 2. WBG Pipeline Project Grants for Aviation Investment in Pacific Island Countries

\begin{tabular}{|c|c|c|c|c|c|}
\hline Country & $\begin{array}{l}\text { Project } \\
\text { Code }\end{array}$ & Project Name & $\begin{array}{l}\text { WBG Commitment } \\
\text { For Aviation } \\
\text { Component }\end{array}$ & Type & $\begin{array}{l}\text { Status as } \\
\text { of end of } \\
\text { FY2015 }\end{array}$ \\
\hline Kiribati & P153381 & $\begin{array}{l}\text { Pacific Aviation Investment-Additional } \\
\text { Financing }\end{array}$ & $\$ 5.8 \mathrm{M}$ & IDA Grant & Pipeline \\
\hline Samoa & P157241 & $\begin{array}{l}\text { Pacific Aviation Investment-Additional } \\
\text { Financing }\end{array}$ & $\$ 15.3 \mathrm{M}$ & IDA Grant & Pipeline \\
\hline Tonga & P156018 & $\begin{array}{l}\text { Pacific Aviation Investment-Additional } \\
\text { Financing }\end{array}$ & $\$ 7.3 \mathrm{M}$ & IDA Grant & Pipeline \\
\hline Tuvalu & P157779 & $\begin{array}{l}\text { Pacific Aviation Investment-Additional } \\
\text { Financing II }\end{array}$ & $\$ 1.4 \mathrm{M}$ & IDA Grant & Pipeline \\
\hline \multicolumn{3}{|c|}{ Total Pipeline IDA grant as of 2015} & $\$ 29.8 \mathrm{M}$ & & \\
\hline
\end{tabular}


2. Aviation Sector reform (\$3.0 mil)—Support reform through the Pacific Aviation Security Office (PASO) and regionally.

a. Assist in restricting PASO through changing its business model.

b. Provide technical assistance in Kiribati in developing civil aviation technical regulations and manuals and prepare a Civil Aviation Master Plan.

c. Support the Tonga Civil Aviation Department in adopting and implementing the new regulations and the ICAO corrective plan.

3. Strengthening Airport Operations and Management Capacity $(\$ 2.6$ mil $)$-Establish an independent public entity (KAL) for the management and operation of area airports.

4. Project support and training ( $\$ 2.2 \mathrm{mil})$ — support to the project implementation unit, PASO support, a project advisor and a training program for government staff (Note 4).

The Pacific Aviation Investment Program was slated to be completed by 2017. However, a two-year extension of the project was approved in early 2016. Along with the extension, additional funding was approved.

\subsection{Economies of the Pacific Islands}

The island economies of the south pacific have not benefited from the globalization process as have other regions around the world. They rely heavily on foreign aid and tourism. They have limited resources, thus limited exports.

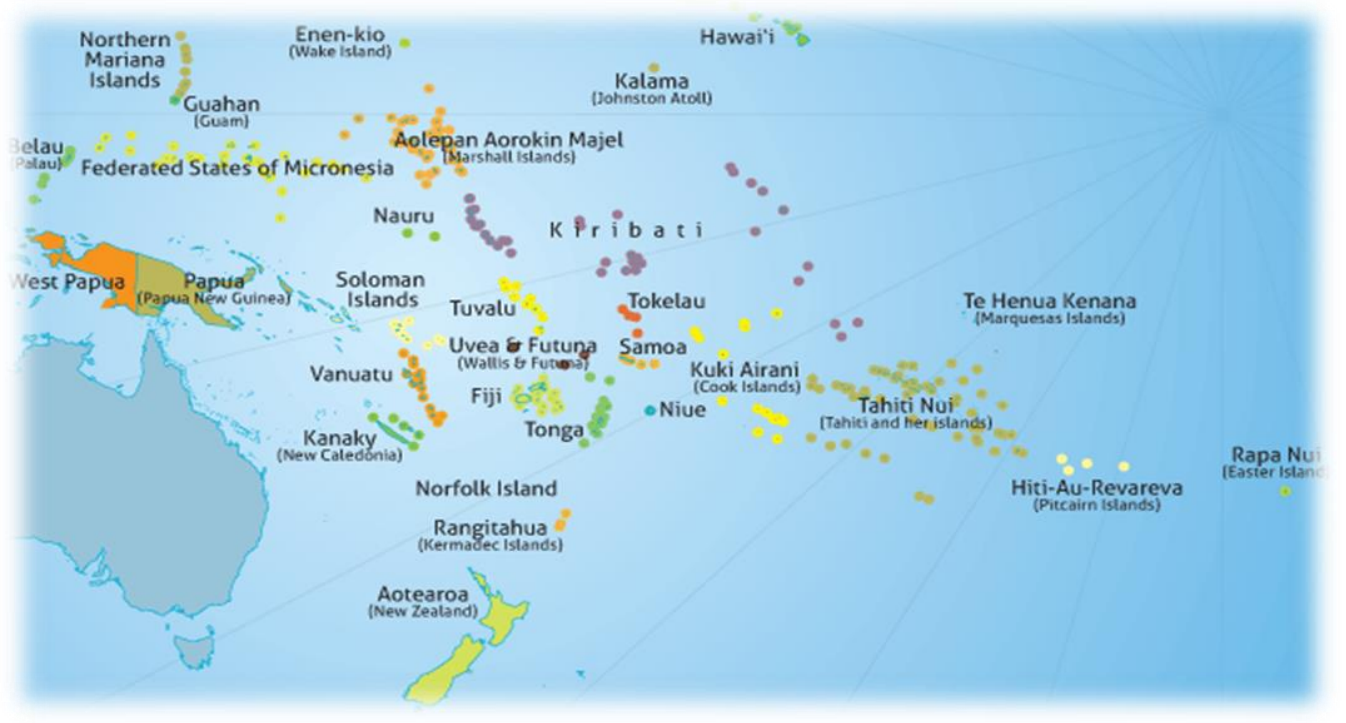

Figure 1. Map of Pacific Island Counties

Source: http://www.hawaii.edu/cpis/oceania_1.html

Figure 1 shows the location of Pacific Island Countries and Table 3 shows the economic data of the five countries highlighted in this study that are receiving grant from the World Bank for aviation projects. This table also shows their gross domestic product, GDP per capita, and gross national income. 
Table 3. The Economic Data of Pacific Island Countries under This Study

\begin{tabular}{lllll}
\hline Country & Currency & GDP\$Million & GDP Per Capita & GNI\$Million \\
\hline Kiribati & Kiribati dollar & $\$ 145.2$ & $\$ 1,291.88$ & $\$ 466.7$ \\
Samoa & Samoan tala & $\$ 761$ & $\$ 3,938.55$ & $\$ 1.106$ \\
Tonga & Tongan pa' anga & $\$ 434.4$ & $\$ 4,114.05$ & $\$ 558$ \\
Tuvalu & Tuvaluan dollar & $\$ 37.86$ & $\$ 3,826.90$ & $\$ 53.68$ \\
Vanuatu & Vanuatu vatu & $\$ 815$ & $\$ 3,147.96$ & $\$ 787.7$ \\
\hline
\end{tabular}

\subsubsection{Kiribati}

The stretch of Pacific Islands known as Kiribati gained its independence from Britain in 1979, just when their deposits of phosphates had been mined out. This mining did build a $\$ 500$ million Revenue Equalization Reserve Fund that continues to provide the country with significant revenue, however. The country is one of the least developed of the Pacific Island nations. They rely on foreign assistance (25 to 50 percent of GDP since 1979), exports of fish and coconuts, and tourism (Note 5). The economy is limited by several factors; unskilled work force, poor infrastructure, remote location, and lack of natural resources. Kiribati is listed as one of the poorer countries in the world's lower middle-income group (Note 6). The influx into the aviation sector from the World Bank would then help in the growth of their exports and in tourism, thus decreasing their reliance on foreign aid. Figure 2 shows Kiribati's GDP growth from 2011 to 2015 (Note 7).

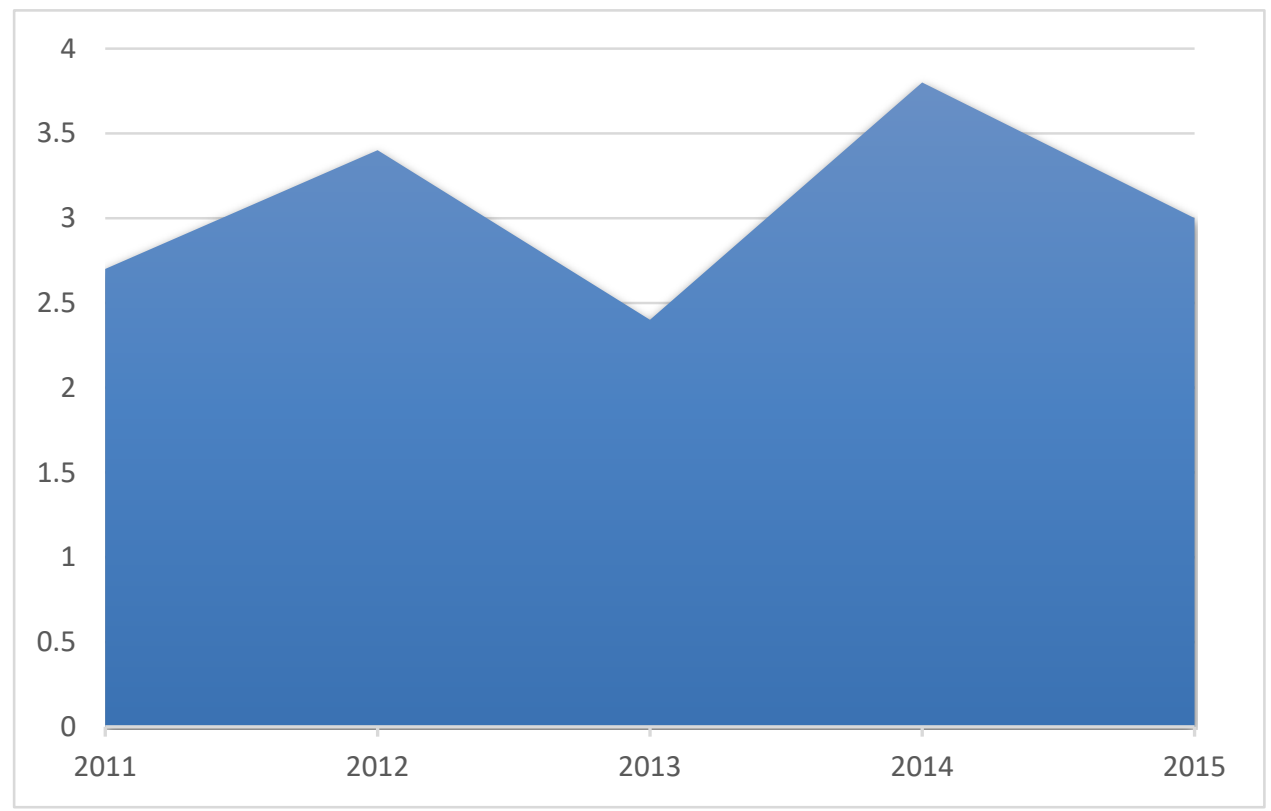

Figure 2. GDP Growth: Kiribati 


\subsubsection{Tonga}

The last Polynesian monarchy, the Kingdom of Tonga, has been independent since it withdrew from the protection of Britain. The royal family and a few other land owners control the politics of the island. Agriculture is their primary sector in their economy with tourism being the second-largest source of earnings. They have a narrow based economy that relies heavily on external aid. Foreign investment in some areas of the economy is restricted. There are no capital markets and with their inadequately developed legal system, there is little in the way of a modern financial sector. Much of the population financially operates outside of the formal banking system within the country (Note 8).

Economic growth in Tonga slowed in 2013 due partly to a drop in construction projects in major public infrastructure. Cyclone Ian, that hit Tonga in January of 2014, slowed growth in 2014. Tonga now faces some serious fiscal problems with the repayment of two large loans coming due. The World Bank investment into the Tonga aviation sector was intended to increase the safety and viability of the airports to increase air traffic for exports and incoming tourism.

Figure 3 shows Tonga's GDP growth from 2011 to 2015.

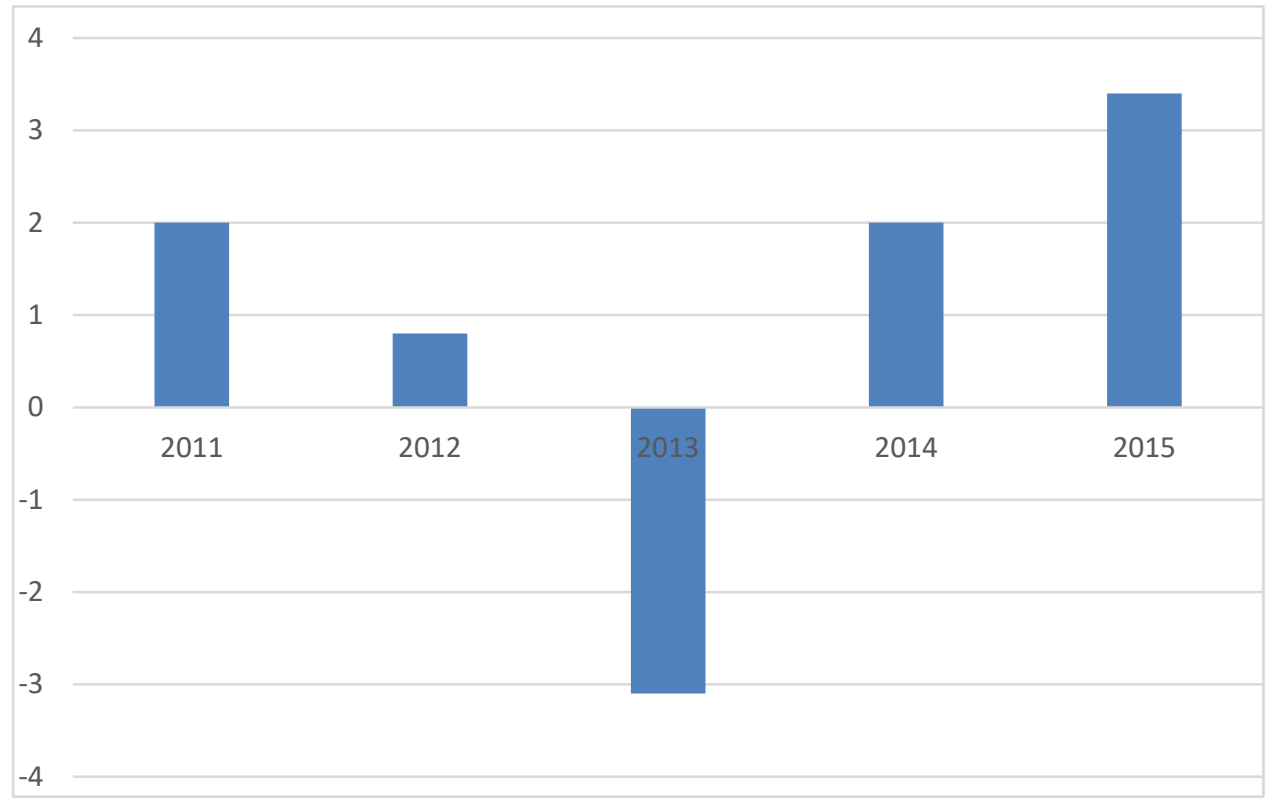

Figure 3. GDP Growth: Tonga

\subsubsection{Samoa}

Samoa is made up of nine different islands; four inhabited and the other fie uninhabited. Upolu is the most developed and populous of the islands; where Savai'i is the largest of the islands. These two islands account for 99 percent of the total population and 96 percent of the total landmass of Samoa (Note 9). More than 198 thousand call Samoa home, but the majority of Samoans now live in the United States, New Zealand and Australia.

The government of Samoa is a parliamentary democracy with an elected Prime Minister. They have two Published by SCHOLINK INC. 
main political parties; the Human Rights Protection Party and the Samoa Democratic United Party. They have no army and very few police are employed on the islands. The villages on the islands tend to be the legal authority (Note 10).

The Samoan economy, with a GDP of $\$ 780$ million, is dependent upon remittances from their fellow Samoans living abroad, tourism and foreign aid. Their economy also relies heavily on agriculture including; coconut, bananas, yams, coffee and cocoa and also the fishing industry. Agriculture and fishing combined employ over 66 percent of the labor force and deliver 90 percent of all exports.

Tourism in Samoa has become an increasingly important sector of the economy. More than 132 thousand tourists visit the islands each year, contributing almost 25 percent of the GDP. In overall revenue, tourism receipts was estimated at $\$ 145,700,000$ for 2014 . Table 6 shows the tourism growth in Samoa for 20 years from 1995 to 2014.

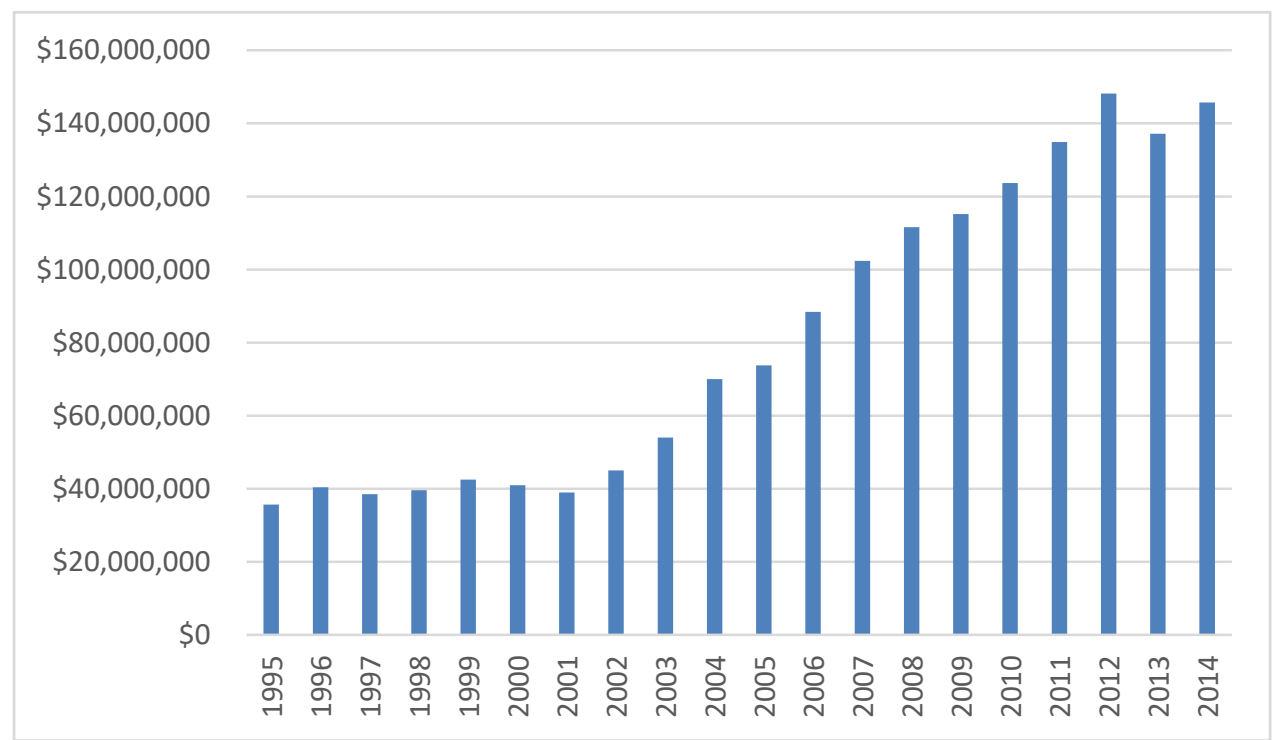

Figure 4. International Tourism Receipts (Note 11)

The World Bank's aviation project included Samoa due to its remoteness, small population and their high dependency on air transport to connect the country to greater markets, and to assist in the tourism industry. The World Bank project plans to increase airside pavement jobs, expand airport taxiways and reconfigure the fueling infrastructure. This coincides with the Samoan governments plan to build a new airport terminal and car park at Faleolo International Airport, near the capital city of Apia (Note 12).

\subsubsection{Tuvalu}

Tuvalu is within the British Commonwealth, but considered an independent island nation. It is comprised of nine separate islands. Based solely on population alone (est. 10,959 July 2016), Tuvalu is the smallest country in the world.

The Tuvalu government is a parliamentary democracy under a constitutional monarchy, making Queen 
Elizabeth II the chief of state. They also have a Prime Minister who is the head of the government, along with a deputy Prime Minister, both of whom are elected by the members of parliament. Tuvalu has no armed forces and only a few police officers, most are located in the capital city of Funafuti, the most populated city (Note 13).

Up until the early 2000's the economy of Tuvalu centered on limited resources, namely coconuts, fish and copra. They also sell stamps, coins and relied on remittances from family members in Australia, New Zealand and the United States. However, in the early 2000's a group of other countries (United Kingdom, Japan, Australia, New Zealand and South Korea) set up the Tuvalu Trust Fund (TTF). The initial donation totaled \$27.1 million, plus Tuvalu added an additional \$38.6 million. Most recently the fund was valued at $\$ 127$ million. The government now obtains more than one-fourth of their revenues from the returns on the TTF. The success of the TTF is due mainly to another fortunate development, the sale of the Tuvalu internet address ".tv". In the late 1990's the government leased the right to the ".tv" internet suffix to a California tech company for $\$ 90$ million over 10 years plus 5 percent of overall revenues. This adds an additional \$20-30 million each year to the TTF (Note 14).

The tourism industry in Tuvalu is almost nonexistent. Its remoteness discourages visitors and business travelers alike. On average, only 1300 people visit the islands every year and half of those are there on business. The primary purpose of the World Bank's aviation project in Tuvalu is to assist in revitalizing the airport and its infrastructure for safety purposes. This will help in the continued operations of the airport and ensure the imports and exports of the country continue.

\subsubsection{Vanuatu}

Vanuatu is an archipelago made up of 83 small islands, 65 of which are inhabited. They gained their independence from France and the United Kingdom in July 1980. They are considered a parliamentary democracy and most of their 200,000 citizens speak English and French. Their labor market is not yet fully developed and their bureaucratic procedures are very complex. The government continues to subsidize most of the state-owned enterprises in the areas of banking, agriculture, broadcasting and aviation/airports. With the government focusing on rebuilding key infrastructure (such as water and sanitation, hospitals and schools) that were damaged in the 2015 cyclone, the islands are still heavily reliant on foreign aid (Note 15).

The Vanuatu GDP was recorded at an estimated \$723 million (2016) and the gross national income per capita based on purchasing power parity around $\$ 2,806$ which has continued to fall since reaching their all-time high in 2009. While this is not a complete representation of the level of development or a measure of welfare in Vanuatu, it is a useful nonmonetary measure of the quality of life. To put the dollar amount into perspective, the greatest GNI per capita comes from the country of Qatar at $\$ 132,099$, while the lowest GNI per capita is measured at $\$ 687$ in Ethiopia. The United States ranks eleventh in GNI per capita at $\$ 53,960$. 


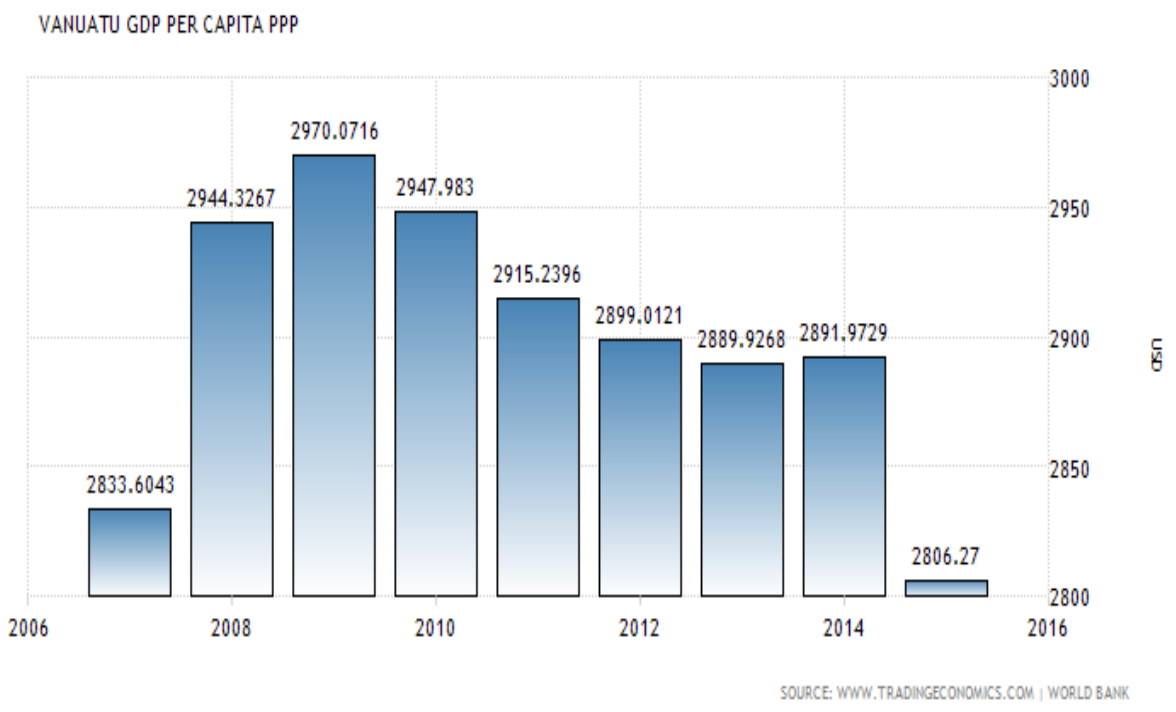

Figure 5. Vaniuta GDP per Capita (Note 16)

Tourism plays a large part in the Vanuatu economy, comprising more than 65 percent of the gross domestic product. With over 200,000 visitors annually, the construction industry has become the second most important contributor to the economic growth of the islands. The main obstacle is that most of the tourism is focused on the most populous island, Efate. Thus, most of the development has been there and has not progressed to the more rural areas (Note 17).

There are 31 airports spread around the islands of Vanuatu. However, only three of those have paved runways. This reduces the chances of tourism expanding outside the main island area and the ideas of diversifying their economy more difficult to pursue. The World Bank Aviation Investment Project in Vanuatu is focused on improving operational safety within the international air transport and the associated infrastructure in Vanuatu. The financing with be used for infrastructure improvements at the three international airports and to assist in maintaining the minimum International Civil Aviation Organization (ICAO) safety and security standards. These improvements include essential upgrades to the runways, terminals and air traffic control management. There will also be improvements made to the baggage handling and cargo screening area for improved safety and security (Note 18).

\subsection{The Global Economic Impact of Air Transport Industry}

The air transport industry is the global network of aircraft manufacturers, airlines, engine manufacturers, airports, air traffic management services, and civil aviation regulators. They all work in tandem to provide a sustainable growth and an economical and reliable mode of moving passengers and cargo with no comparable substitute especially for the long-haul market. The air transport industry is responsible for connecting the global economy, supports a total of 62.7 million jobs globally, and contributes a total of $\$ 2.7$ trillion to global economy including direct, indirect, induced, and the catalytic effects of tourism (Note 19). Air transport continues to create tremendous value for its customers and others in the value chain such as airports, aircraft manufacturers, jet engine producers, and travel facilitators. The world's 
1,402 commercial airlines operate a total fleet of 26,065 aircraft, by serving 17,678 commercial airports globally (Note 20).

The air transport industry has been evolved over the last 40 years. Technological changes and productivity growth has spurred the number of passengers all-time high of 3.6 billion in 2015 (Note 21). In the year 2016 this number is expected to rise to 3.8 billion passengers traveling over some 54,000 routes. The industry has transformed into a comprehensive dynamic environment with many participants which drives economic and social progress, connects people, countries and cultures, provide access to global markets, generates trade and tourism, and forges links between developed and developing nations. The global air transport provides the following benefits (Note 22):

1. Vital economic benefits-Aviation provides the only worldwide rapid air transport system which makes it essential for global business and tourism. Economic benefits for 2015 are as follows:

a. Total global economic impact of \$2.7 trillion including direct, indirect, induced, and the catalytic effects of tourism.

b. Transported approximately 3.6 billion passengers.

c. Carried 51.2 million tons of freight and $35 \%$ of interregional exports of goods by value.

d. $54 \%$ of international tourism travel by air.

e. Research conducted in the U.S. suggested that every $\$ 100$ million invested in aviation yields an extra $\$ 70$ million in GDP year after year.

2. Great employment opportunities - Air transport supports 62.7 million jobs globally.

a. $\quad$ It directly creates 9.9 million jobs worldwide.

b. Airlines, airports, and air navigation service providers employ 8.9 million people.

c. The civil Aerospace sector employs 1.1 million people.

d. 11.2 million indirect jobs are created via purchases of goods and services from companies in the air transport supply chain.

e. $\quad 5.2$ million jobs are induced through spending by industry employees.

f. Almost 36.3 million direct and indirect jobs are created through air transport's catalytic impacts on tourism.

3. Significant social benefits-Aviation broadens people's leisure and cultural experiences via wide choices/affordable access to destinations across the globe.

a. Improves living standards and alleviate poverty through tourism.

b. Often serves as the only means of transportation to remote areas promoting social inclusion.

c. Contributes to sustainable development by facilitating tourism and trade, generating economic growth, creating jobs, and increasing tax revenues.

d. Facilitate the delivery of emergency and humanitarian aid relief.

e. Swift delivery of medical supplies and organs for transplantation.

4. Efficient user of resources and infrastructure-Aviation occupancy (Load factor) rates of $82.44 \%$ for 2016 (Note 23) are better than those of road and rail. Modern aircraft achieve fuel efficiencies of 67 
passenger miles per gallon.

5. Responsibly reducing environmental impact-Aircraft entering today's fleets are $20 \%$ quieter with 50\% reduction in noise during take-off and landing. In addition, the new aircraft are $70 \%$ fuel efficient than they were 40 years ago, reducing carbon monoxide emissions by about $50 \%$.

\section{The Economic Impact of Airports}

Although airports are part of the air transport industry, they play an eminent role in the economic development of a region, as well as the nation. Airports facilitate the fast movement of passengers and goods, thereby fostering trade and commerce. Airports offer increased accessibility which in turn fuels the tourism sector. With an increase in the number of tourism, more money flows into the local economy, increase economic activity and employment, and in turn increase the standard of living in the region. Therefore, the availability of an airport provides a boost to the GDP of region and positively impact the national economy.

\subsection{Economic Impact of Investing in Aviation Operational Safety}

Whether an entity is a public one or a private one, they are all challenged with economic problems. One persistent question being asked is: What capital projects should be pursued with the value that is to be derived from undertaking said project not fully being understood. Economic analysis provides an efficient way of answering these types of questions (Note 24).

In general, projects should be undertaken only when the value resulting from the project equals or exceeds the costs. As with the projects being undertaken by the World Bank in the Pacific Islands, the first step was to identify the effects that will occur and ascertain who will be affected as a result of the project. The second step is to calculate the effects in some type of physical or time-based unit. Finally, those units must be valued into dollars. Once this process is complete the total monetary benefits can be calculated and attributed to the project (Note 24).

In a study done by the Center for Aviation Safety Research a macro-to-micro analytical framework was used to show the financial benefits of safety programs. While this study dealt mainly with airlines, it still shows the financial benefits of safety programs in the aviation sector. Safety experts realize that there are humanistic advantages to implementing safety programs. However, documenting the overall financial benefits can be difficult due to the intricacy of placing a monetary value on those humanistic advantages (Note 25).

In looking at the types of projects the World Bank is involved with, i.e., improving runways, taxiways, etc., the typical benefits include: reduced aircraft, passenger and cargo delays, greater schedule predictability, improved efficiency of traffic flows, reduced aircraft operating costs, ability to accommodate larger, faster, more efficient aircraft, reduction of emissions, and safety improvements. 


\section{Conclusion}

Aviation infrastructure and airports play a major role in the globalization of our economies. Airports are the major part of a country's infrastructure and foster international commerce and tourism. Airports boost employment, both direct and in-direct. They offer enhanced accessibility, which fuels tourism, which in turn, fuels more employment and economic value. With increased employment and economic movement, the standard of living in the region will change (Note 26). The improvements being funded by the World Bank in the Pacific Island region should lead to higher employment rates, increased tourism, thus a higher standard of living in that region.

\section{References}

Aeronewstv. (2015). How many commercial airports are there in the world? Airports, World Airports, Economic Impact of Airports. Economy Watch. Retrieved June 29, 2010, from http://www.economywatch.com/world-country/airports.html

Asian Development Bank. (2016). Kiribati: Economy. Retrieved from http://www.adb.org/countries/kiribati/economy\#tabs-0-1

Dornan, M., \& Cain, T. (2015). Tourism and economic diversification in Vanuatu. Retrieved May 20, 2017, from http://www.devpolicy.org/tourism-and-economic-diversification-in-vanuatu-20150616/

FAA Airport Benefit-Cost Analysis Guidance. (1999, December 15). Office of Aviation Policy and Plans, Federal Aviation Administration. $\quad$ Retrieved from https://www.faa.gov/regulations_policies/policy_guidance/benefit_cost/media/1999

Five-Year Plan Highlights Opportunities and Risk for Nine Pacific Island Nations. (2017, February 28). $\begin{array}{llll}\text { Retrieved } & \text { May } & 20, & \text { 2017, }\end{array}$ http://www.worldbank.org/en/news/press-release/2017/02/28/five-year-plan-highlights-opportuniti es-and-risks-for-nine-pacific-island-nations

IATA. (2015). Fact Sheet: Economic \& Social Benefits of Air Transport.

Index of Economic Freedom. (2016). Kiribati. Retrieved from http://www.heritage.org/index/country/kiribati

Index of Economic Freedom. (2016). Tonga. Retrieved from http://www.heritage.org/index/country/tonga

Index of Economic Freedom. (2017). Vanuatu. Retrieved from http://www.heritage.org/index/country/vanuatu

Lercel, D., Steckel, R., Mondello, S., \& Patankar, M. (2011, February). Aviation Safety Management Systems Return on Investment Study. Center for Aviation Safety Research.

Pacific Island Economies: Building a Resilient Economic Base for the Twenty-First Century. (1996, April). Retrieved from http://www.elibrary.worldbank.org/doi/abs/10.1596/0-8213-3554-5

Samoa Travel Guide. Geography. (2017). Retrieved from http://www.samoa.southpacific.org/samoa/geography.html 

http://www.samoa.southpacific.org/samoa/government.html

Samoa: World Bank aviation project expanded. (2016, June). Retrieved from http://www.worldbank.org/en/news/press-release/2016/06/06/world-bank-aviation-project-expand ed-in-samoa

Samoa-International

Tourism.

(2014)

Retrieved

from http://www.indexmundi.com/facts/samoa/international-tourism

Schlumberger, Charles. (2015). Air Transportation Annual Report OFVLR, World Bank Group.

The world Bank Projects \& Programs. (n.d.). Retrieved May 20, 2017, from http://www.worldbank.org/en/country/pacificislands/projects

The World Bank. (n.d.). Vanuatu Aviation Investment Project. Retrieved from http://www.projects.worldbank.org/P161454?lang=en

The World Bank's Pacific Island Member Countries. (n.d.). Retrieved May 20, 2017, from http://www.worldbank.org/en/ country/pacificislands/overview

$\begin{array}{llll}\text { The } \quad \text { Forld } & \text { Factbook. } & \text { (2016). }\end{array}$ http://www.cia.gov/library/publications/the-world-factbook/geos/kr.html

The World Factbook-Tuvalu. (n.d.). Central Intelligence Agency. Retrieved from https://www.cia.gov/library/publications/the-world-factbook/geos/tv.html

Tonga Second Inclusive Growth Development Policy Operation. (n.d.). Retrieved May 20, 2017, from http://www.projects.worldbank.org/P159262?lang=en

Vanuatu Aviation Investment Project Additional Financing. (n.d.). Retrieved May 20, 2017, from http://www.documents.worldbank.org/curated/en/958521484276488499/Vanuatu-Aviation-Invest ment-Project-additional-financing

Vanuatu GDP. (n.d.). Trading Economics. Retrieved from http://www.tradingeconomics.com/vanuatu/gdp-per-capita-ppp

World Bank. (2011). Integrated Safeguards Data Sheet for the Pacific Aviation Investment Project.

World Bank. (2011). Project Information Document (PID), Concept Stage.

Worldmark Encyclopedia of Nations-Tuvalu. (n.d.). Retrieved from http://www.encyclopedia.com/places/australia-and-oceania/pacific-islands-political-geography/tuv alu

\section{Notes}

Note 1. World Bank. Project Information Document (PID), Concept Stage, 2011.

Note 2. 2015 Air Transport Annual Report, OFVLR, March 10, 2016.

Note 3. World Bank. Project Information Document (PID), Concept Stage, 2011.

Note 4. World Bank. Integrated Safeguards Data Sheet for the Pacific Aviation Investment Project. 2011.

Published by SCHOLINK INC. 
Note 5. 2016 Index of Economic Freedom: Kiribati. Retrieved from http://www.heritage.org/index/country/kiribati

Note 6. Central Intelligence Agency. The World Factbook. Retrieved from http://www.cia.gov/library/publications/the-world-factbook/geos/kr.html

Note 7. Asian Development Bank. Kiribati: Economy. Retrieved from http://www.adb.org/countries/kiribati/economy\#tabs-0-1

Note 8. 2016 Index of Economic Freedom. Tonga. Retrieved from http://www.heritage.org/index/country/tonga

Note 9. Samoa Travel Guide. Geography. Retrieved from http://www.samoa.southpacific.org/samoa/geography.html

Note 10. Samoa Travel Guide. Government. Retrieved from http://www.samoa.southpacific.org/samoa/government.html

Note 11. Samoa: International Retrieved from http://www.indexmundi.com/facts/samoa/international-tourism

Note 12. Samoa: World Bank aviation project expanded. Retrieved from http://www.hworldbank.org/en/news/press-release/2016/06/06/world-bank-aviation-project-expanded-i n-samoa

Note 13. The World Factbook-Tuvalu. Central Intelligence Agency. Retrieved from http://www.cia.gov/library/publications/the-world-factbook/geos/tv.html

Note 14. Worldmark Encyclopedia of Nations-Tuvalu. Retrieved from http://www.encyclopedia.com/places/australia-and-oceania/pacific-islands-political-geography/tuvalu

Note 15. 2017 Index of Economic Freedom-Vanuatu. Retrieved from http://www.heritage.org/index/country/vanuatu

Note 16. Vanuatu GDP. Trading Economics. Retrieved from http://www.tradingeconomics.com/vanuatu/gdp-per-capita-ppp

Note 17. Dornan, M., \& Cain, T. (2015). Tourism and economic diversification in Vanuatu. Retrieved from http://www.devpolicy.org/tourism-and-economic-diversification-in-vanuatu-20150616/

Note 18. The World Bank. Vanuatu Aviation Investment Project. Retrieved from http://www.projects.worldbank.org/P161454?lang=en

Note 19. IATA. (2015). Fact Sheet: Economic \& Social Benefits of Air Transport.

Note 20. Aeronewstv. (2015). How many commercial airports are there in the world?

Note 21. Business, May 2015. Airline.

Note 22. IATA. (2015). Fact Sheet: Economic \& Social Benefits of Air Transport.

Note 23. Bureau of transportation statistics, 2016.

Note 24. FAA Airport Benefit-Cost Analysis Guidance. Office of Aviation Policy and Plans, Federal Aviation Administration. Retrieved December $\quad 15, \quad 1999$ from https://www.faa.gov/regulations_policies/policy_guidance/benefit_cost/media/1999_FAA_Airport_Ben 
efit_Cost_Analysis_Guidance.pdf

Note 25. Lercel, D., Steckel, R., Mondello, S., \& Patankar, M. (2011, February). Aviation Safety Management Systems Return on Investment Study. Center for Aviation Safety Research.

Note 26. Airports, World Airports, Economic Impact of Airports. (2010, June 29). Economy Watch. http://www.economywatch.com/world-country/airports.html 